\title{
PENGARUH STRATEGI PEMBELAJARAN DAN KECERDASAN LOGIS MATEMATIS TERHADAP HASIL BELAJAR MATEMATIKA SEKOLAH DASAR KELAS VI
}

\author{
Moch. Sukardjo ${ }^{1)}$, Krisna Yusdiningtias ${ }^{2)}$ \\ ${ }^{1)}$ Fakultas Teknik, Universitas Negeri Jakarta, Indonesia \\ Email: msoekardjo@unj.ac.id
}

\begin{abstract}
The accuracy in choosing a learning strategy is an important part in the effort to improve the achievement of student learning outcomes. Hence, this study aims to determine the effect of learning strategy and logical-mathematical intelligence as well as its interaction with mathematics learning outcomes. This study used on experimental research by level $2 \times 2$ with 18 people were taken by simple random sampling in Islamic Elementary School (SD Islam) Karya mukti. The result of this research found that there is an interaction effect between learning and logical-mathematical intelligence to match learning outcomes. Thus the selection of the relevant strategy, the acquisition of mathematics learning outcomes are influenced by the ability of the teacher to understand the characteristics of their students. The strategy applied to optimize the mathematics teacher of mathematics learning outcomes of students who have a logicalmathematical intelligence.
\end{abstract}

Keywords : strategy, logical-mathematical intelligence, learning outcomes mathematics

Abstrak: Ketepatan dalam memilih strategi pembelajaran adalah bagian penting
dalam upaya meningkatkan pencapaian hasil belajar siswa. Oleh karenanya
penelitian ini bertujuan untuk mengetahui pengaruh strategi pembelajaran dan
kecerdasam logis-matematis terhadap hasil belajar matematika. Penelitian ini
menggunakan penelitian eksperimen rancangan treatment by level 2 x 2 dengan
sampel 18 orang diambil secara simple random sampling di SD Islam karya
mukti. Hasil penelitian ini menunjukkan bahwa ada pengaruh interaksi antara
strategi pembelajaran dan kecerdasan logis matematis terhadap hasil belajar
matematika. Sehingga pemilihan strategi pembelajaran yang sesuai dipengaruhi
oleh kemampuan guru dalam memahami karakteristik siswanya. Strategi
pembelajaran yang diterapkan guru dapat mengoptimalkan hasil belajar
matematika siswa yang memiliki kecerdasan logis matematis yang berbeda-beda. Kata Kunci: strategi pembelajaran, kecerdasan logis matematis, hasil belajar matematika.

\section{PENDAHULUAN}

Pendidikan merupakan suatu usaha untuk menumbuh kembangkan potensi sumber daya manusia melalui kegiatan belajar. Untuk itu pendidikan bersifat dinamis sehingga selalu menuntut adanya suatu perbaikan. Pendidikan sangat berperan dalam proses kehidupan, karena dengan pendidikan akan melahirkan manusia sebagai sumber daya yang berkualitas. Sumber daya manusia yang berkualitas akan 
mampu mengantisipasi setiap perubahan yang terjadi dan mampu menyesuaikan diri.

Sekolah merupakan

laboratorium bagi siswa untuk belajar memecahkan masalah karena setiap siswa memiliki kebutuhan untuk menyelidiki lingkungan mereka dan membangun secara pribadi pengetahuannya. Melalui kegiatan tersebut siswa menemukan ide mereka sendiri dan memperoleh makna oleh mereka sendiri. Guru sebagai fasilitator memberi bimbingan kepada siswa guna mengatasi masalah yang melampaui tingkat perkembangan saat itu. Artinya, siswa memperoleh sendiri pengetahuannya dan guru lebih berperan sebagai fasilitator dan membimbing siswa pada proses belajarnya.

Ketepatan dalam memilih
strategi pembelajaran yang sesuai
dengan tujuan pembelajaran, pada dasarnya bertujuan untuk meningkatkan pencapaian hasil belajar siswa. Standar minimal hasil belajar dinyatakan dalam Kriteria Ketuntasan Minimal (KKM), Kriteria Ketuntatsan Minimal dianalisis dan ditetapkan oleh guru pada awal tahun pelajaran dengan memperhatikan faktor : (1) input (kemampuan) siswa, (2) tingkat kompleksitas materi ajar, (3) sarana prasarana pendukung.

Melalui pemilihan strategi pembelajaran yang sesuai dengan kelengkapan perangkat pembelajaran yang memadai, seharusnya guru tidak akan menemukan kesulitan dalam membimbing siswa untuk mencapai Kriteria Ketuntasan Minimal yang ditetapkan. Kenyataan di lapangan menunjukkan berdasarkan observasi peneliti saat ini strategi pembelajaran di kelas masih berpusat pada guru dan materi ajar disampaikan langsung oleh guru. Pola pembelajaran cenderung "text book oriented" dan tidak terkait dengan kehidupan sehari-hari siswa.

Berdasarkan survey yang dilakukan peneliti bahwa nilai mata pelajaran Matematika belum menunjukkan hasil belajar siswa yang optimal sesuai dengan Kriteria Ketuntasan Minimal yang telah ditetapkan yaitu 75 Berdasarkan hasil belajar siswa kelas V-A, V-B dan V-C diperoleh data nilai siswa sebagai berikut : (1) siswa yang mendapatkan nilai dengan interval nilai 90-100 yaitu sebanyak 4 siswa, (2) siswa yang mendapatkan nilai dengan interval nilai 80-89 yaitu sebanyak 21 siswa, (3) siswa yang mendapatrkan nilai dengan interval nilai 75-79 yaitu sebanyak 26 siswa, Dan (4) siswa yang mendapatkan nilai dengan interval nilai $\leq 75$ yaitu sebanyaj 33 siswa.

Salah satu aspek penyebab rendahnya hasil belajar siswa yaitu dominannya proses pembelajaran ekspositori. Pada pembelajaran ini suasana kelas cenderung berpusat pada guru, sehingga siswa menjadi pasif. Meskipun demikian, guru lebih suka menerapkan strategi tersebut, sebab tidak memerlukan alat dan bahan praktik, cukup menjelaskan konsepkonsep yang ada pada buku ajar atau referensi lain. Dalam hal ini, siswa tidak diajarkan bagaimana cara berpikir dan memotivasi diri sendiri, padahal aspekaspek tersebut merupakan kunci keberhasilan dalam suatu pembelajaran, masalah ini banyak dijumpai dalam proses pembelajaran di kelas. Ini mengakibatkan siswa menjadi pasif dan tidak fokus sehingga terjadi kejenuhan belajar pada saat proses pembelajaran. Untuk itu seorang guru dituntut untuk dapat menunjukkan keahlian di depan kelas. Guru harus mampu memotivasi peserta didik, mampu mengekspresikan gagasan-gagasan, mampu menggunakan media belajar dan memilih pendekatan 
dengan strategi pembelajaran yang sesuai, membuat konsep materi yang mudah dipahami dan bermakna.

Salah satu strategi yang dapat digunakan sesuai dengan penerapan pembelajaran siswa aktif dan bermakna yaitu strategi pembelajaran kontekstual (Contextual Teaching and Learning) sebagaimana telah disebutkan oleh (Corno, L. (1989). Pembelajaran kontekstual yaitu konsep belajar yang membantu guru mengaitkan antara materi yang diajarkannya dengan situasi dunia nyata siswa dan mendorong siswa membuat hubungan antara pengetahuan yang dimilikinya dengan penerapannya dalam kehidupan mereka sehari-hari (Trianto, 2009:107).

Matematika merupakan mata pelajaran yang menakutkan bagi sebagian siswa (lihat Begg, A. (2005)., padahal matematika sangat penting untuk diterapkan dalam kehidupan kita sehari-hari. Kegiatan yang paling sering memerlukan penerapan matematika dalam keseharian kita yaitu ketika kita sedang bertransaksi, mengkonversi mata uang, menghitung pajak, menyusun budget pengeluaran, menghitung bunga bank, dan menghitung besar luas suatu ruang. Di dalam proses pembelajaran, guru di harapkan dapat menyajikan materi matematika dengan menyenangkan bagi siswa. Mengajarkan matematika sejak dini membuat siswa jadi menyenangi matematika yang akan berguna pada kehidupan sehari-harinya kelak.

Melalui strategi pembelajaran yang dapat memberikan simulasi kepada siswa untuk memberikan pengalaman langsung diharapkan dapat mengembangkan aspek kecerdasan jamak siswa.

Berdasarkan uraian yang telah dikemukakan, maka peran strategi pembelajaran penting dalam perolehan hasil belajar matematika dengan memperhatikan kecerdasan logis matematis siswa. Oleh karena itu, perlu adanya penelitian mengenai pengaruh strategi pembelajaran dan kecerdasan logis matematis siswa terhadap hasil belajar matematika kelas VI. Hasil penelitian ini secara teoretis diharapkan dapat menambah wawasan keilmuan dan pengetahuan dalam bidang Matematika baik bagi peneliti sendiri maupun para akademisi yang bergerak dalam dunia pendidikan. Secara praktis hasil penelitian ini dapat bermanfaat bagi guru, siswa maupun para peneliti dalam bidang matematika.

Pendidikan Matematika sangat penting dalam berbagai kondisi kehidupan. Banyak permasalahan dan kegiatan dalam hidup kita yang harus diselesaikan dengan menggunakan ilmu matematika seperti menghitung, mengukur dan lain-lain. Van De Walle mengemukakan bahwa Matematika adalah ilmu tentang pola dan urutan (Van De Walle, 2006:13).

Peran Matematika semakin penting karena banyaknya informasi yang disampaikan dalam bahasa Matematika seperti aljabar, analisis, tabel, grafik, diagram, matematika diskrit dan lain-lain. Standar kompetensi Mata Pelajaran Matematika Sekolah Dasar, menyatakan bahwa Matematika berfungsi untuk mengembangkan kemampuan bernalar, mempunyai kegiatan penyelidikan, eksplorasi dan eksperimen sebagai alat komunikasi melalui simbol, tabel, grafik, diagram dalam menjelaskan gagasan (Depdiknas, 2003:6).

Strategi pembelajaran pada penelitian adalah sebuah rencana atau pola yang dibuat untuk mengatur jalannya proses pembelajaran didalam kelas maupun tempat lain. Menurut Miarso bahwa strategi pembelajaran adalah pendekatan menyeluruh pembelajaran dalam suatu sistem 
pembelajaran yang berupa pedoman umum dan kerangka kegiatan untuk mencapai tujuan umum pembelajaran yang dijabarkan dari pandangan falsafah dan atau teori belajar tertentu (Miarso, 2013:530). Dalam perkembangan mental siswa di sekolah meliputi kemampuan untuk bekerja secara abstrak menuju konseptual. Implikasinya terhadap pembelajaran harus memberikan pengalaman yang bervariasi dengan strategi yang relevan dan bervariasi. Pembelajaran harus Strategi pembelajaran yang digunakan untuk mencakup sebagai aspek dalam mengurutkan dan mengorganisasikan informasi serta mengambil keputusan tentang bagaimana cara menyajikannya. Pengertian tersebut mengandung tiga kegiatan pokok dalam strategi pembelajaran, yaitu: pemilihan media, pengurutan materi pembelajaran dan pemotongan materi pembelajaran. Untuk pemilihan media pembelajaran, harus mempertimbangkan konteks pembelajaran, keterampilan dan situasi praktis di lapangan. Urutan materi pembelajaran ditentukan berdasarkan analisis materi pembelajaran. Pada bagian lain, pemotongan materi pembelajaran didasarkan atas beberapa pertimbangan antara lain: (1) usia siswa, (2) kompleksitas materi dan (3) jenis kegiatan belajar yang akan terjadi. Strategi pembelajaran yang akan dicoba adalah strategi pembelajaran kontekstual, sedangkan sebagai kelas kontrol digunakan strategi pembelajaran ekspositori yang berlaku saat ini.

Johnson berpendapat bahwa Contextual Teaching and Learning merupakan sebuah proses pendidikan yang bertujuan menolong para siswa melihat makna di dalam materi akademik yang mereka pelajari dengan cara menghubungkan subjek-subjek akademik dengan konteks dalam kehidupan keseharian mereka, yaitu dengan konteks keadaan pribadi, sosial dan budaya mereka (Johnson, 2011:67) Strategi pembelajaran kontekstual merupakan konsep yang membantu guru mengaitkan antara materi yang diajarkannya dengan situasi nyata dan mendorong siswa membuat hubungan antara pengetahuan yang dimilikinya dengan penerapannya dalam kehidupan mereka sebagai anggota keluarga dan masyarakat. Pembelajaran kontekstual juga dikenal dengan experiental learning, real world education, active learning dan learned centered instruction. Asumsi pembelajaran tersebut adalah : (a) belajar yang baik adalah jika siswa terlibat secara pribadi dalam pengalaman belajarnya, (b) pengetahuan harus ditemukan siswa sendiri agar mereka memiliki arti atau dapat membuat distingsi berbagai perilaku yang mereka pelajari, (c) siswa harus memiliki komitmen terhadap belajar dalam keadaan paling tinggi dan berusaha secara aktif untuk mencapainya dalam kerangka kerja tertentu (Suprijono, 2011:79). Landasan filosofis CTL adalah konstruktivisme, yaitu filosofi belajar yang menekankan bahwa belajar tidak hanya sekedar menghafal, tetapi siswa harus mengkontruksikan pengetahuan dibenak mereka sendiri. Bahwa pengetahuan tidak dapat dipisah-pisahkan menjadi fakta atau proposisi yang terpisah, tetapi mencerminkan keterampilan yang dapat diterapkan.

Joyce and Wail menggunakan istilah model pembelajaran untuk strategi pembelajaran. Disebutkan, strategi pembelajaran adalah sebuah rencana atau pola yang dapat digunakan untuk membentuk kurikulum (arah jangka panjang dari belajar), mendesain materi pelajaran, dan untuk pedoman pembelajaran didalam kelas maupun tempat lain (Yamin, 2013:5). 
Prinsip ilmiah dalam pembelajaran kontekstual ada 3 yaitu saling ketergantungan, diferensiasi dan pengaturan diri. (1) Prisip saling ketergantungan, (2) Prinsip Diferensiasi , Dan (3) prinsip pengaturan diri (.Johnson, 2011:68).

COR (Center for Occupational Research) menjabarkan lima konsep CTL yang disingkat REACT, yaitu Relating, Experiencing, Applying, Cooperating, dan Transfering. Relating adalah bentuk belajar dalam konteks kehidupan nyata atau pengalaman nyata. Experiencing adalah belajar dalam konteks eksplorasi, penemuan, dan penciptaan. Applying adalah belajar dalam bentuk penerapan hasil belajar ke dalam penggunaan dan kebutuhan praktis. Cooperating adalah belajar dalam bentuk berbagi informasi dan pengalaman, saling merespons, dan saling berkomunikasi. Transfering adalah kegiatan belajar dalam bentuk memanfaatkan pengetahuan dan pengalaman berdasarkan konteks baru untuk mendapatkan pengetahuan dan pengalaman belajar yang baru (Muslich, 2009: 41-42).

$\begin{array}{rr}\text { Strategi } & \text { pembelajaran } \\ \text { ekspositori merupakan proses }\end{array}$ pembelajaran yang lebih berpusat pada guru (teacher centered), guru menjadi sumber dan pemberi informasi utama. Dalam strategi pembelajaran ekspositori guru menyajikan bahan pelajaran secara utuh atau menyeluruh, lengkap dan sistematis, dengan menyampaikan secara verbal. Pembelajaran ini tidak lebih dari metode ceramah yang dimodifikasi sedemikian rupa, sehingga para siswa tidak hanya tinggal diam secara pasif seperti dalam pembelajaran ceramah yang tradisional (Syah, 1995:245). Prosedur penyajian materi pelajaran dengan strategi ekspositori ini adalah: Pertama, persiapan (preparation) yakni guru mempersiapkan bahan pelajaran yang lengkap dan sistematis. Kedua, apersepsi (apperception) yakni guru bertanya atau menguraikan materi untuk mengarahkan perhatian para siswa terhadap materi yang hendak disajikan. Ketiga, penyajian (presentation), yakni guru menyajikan bahan pelajaran secara lisan atau dengan cara menyuruh siswa membaca bahan yang berkenaan dari buku teks, diktat atau tulisan di papan tulis. Keempat, penyebutan kembali (recitation), yakni guru menyuruh siswa menyatakan kembali pokok kandungan materi pelajaran yang telah disajikan dengan menggunakan kata-kata sendiri (Syah, 1995:246).

Menurut Romiszowski strategi pembelajaran ekspositori didasarkan pada teori pemprosesan informasi. Strategi ini erat kaitannya dengan pendekatan deduktif dimana metode ini dimulai dengan penyajian informasi mengenai prinsip dan kaidah, kemudian di ikuti dengan tes penguasaan, penerapan dalam bentuk contoh dan penerapan dalam situasi tertentu (Romiszowski, 1981:293). Senada dengan Romiszowski, Miarso menjelaskan bahwa strategi pembelajaran ekspositori didasarkan pada teori pemrosesan informasi, yang menjelaskan bahwa proses belajar berlangsung sebagai berikut: (1) siswa menerima informasi, prinsip atau dalil dengan contoh-contoh, (2) terjadi pemahaman pada diri siswa, (3) siswa menarik kesimpulan berdasar kepentingan, dan (4) terbentuknya tindakan pada siswa yang merupakan hasil pengolahan informasi, prinsip sesuai dengan situasi yang sebenarnya (Miarso, 2013:530-531).

Roy Killen menamakan strategi pembelajaran ekspositori ini dengan istilah strategi pembelajaran langsung (direct instruction) (Sanjaya, 2006:179). 
Melalui strategi ini guru menyampaikan materi pembelajaran secara terstruktur dengan harapan materi bahan ajar yang disampaikan itu dapat dikuasai oleh siswa dengan baik. Strategi pembelajaran ekspositori merupakan bentuk pendekatan pembelajaran yang berorientasi kepada guru, karena dalam strategi pembelajaran ini guru memegang peranan yang sangat dominan. Ciri-ciri pembelajaran langsung adalah : (1) adanya tujuan pembelajaran dan prosedur penilaian hasil belajar, (2) sintaks atau pola keseluruhan dan alur kegiatan pembelajaran, dan (3) sistem pengelolaan dari lingkungan belajar yang mendukung berlangsung dan berhasilnya pengajaran (Trianto, 2009: 41-42).

$\begin{array}{ccc}\text { Menurut Miarso ada } 4 & \text { langkah } \\ \text { atau tahapan dalam strategi }\end{array}$ pembelajaran ekspositori, yaitu : (1) Persiapan yaitu guru mempersiapkan bahan secara lengkap, sistematis dan menyampaikan tujuan, apersepsi dan memberikan ilustrasi atau gambaran singkat tentang materi yang telah diterima untuk dikaitkan dengan materi yang akan diajarkan. (2) Pendahuluan, yaitu guru memberikan tes penguasaan, serta penyajian ulang materi sebelumnya untuk dikaitkan dengan materi yang akan diajarkan, (3) Penyajian, yaitu guru menyajikan bahan dengan penjelasan secara rinci dari materi baru yang telah dipersiapkan dari buku teks dan pengembangannya dari guru. Diberikan kesempatan penerapan dalam bentuk contoh dan soal, Dan (4) Penutup, yaitu guru memberi tugas, latihan atau pertanyaan yang harus dijawab dan dikerjakan siswa dengan jumlah dan tingkat kesulitan yang bertambah, yang dilanjutkan dengan pengungkapan informasi atau materi dengan kata-kata sendiri secara lisan maupun tertulis (Miarso, 2013:531).
Kecerdasan logis-matematis atau dikenal dengan istilah cerdas angka termasuk kemampuan ilmiah (scientific) yang sering disebut dengan berpikir kritis. Gardner seperti mendefinisikan bahwa kecerdasan adalah kemampuan untuk menyelesaikan masalah atau menciptakan sesuatu yang bernilai dalam suatu budaya (Hoerr, 2007:11).

Smith menyebutkan orang yang memiliki kecerdasan ini cenderung melakukan sesuatu dengan data untuk melihat pola-pola dan hubungan (Yaumi, 2013: 63). Selain itu, mereka juga sangat menyukai angka-angka dan dapat menginterpretasi data serta menganalisis pola-pola abstrak dengan mudah. Lwin mendefinisikan kecerdasan logis-matematis sebagai kemampuan untuk menangani bilangan dan perhitungan, pola dan pemikiran logis dan ilmiah (Lwin, 2008:43). Anak-anak yang cerdas secara matematis sering tertarik dengan bilangan dan pola dari usia yang sangat muda. Mereka menikmati berhitung dan dengan cepat belajar menambah, mengurangi, mengalikan dan membagi. Selain itu, anak-anak yang terampil dalam matematika cepat memahami konsep waktu. Anak-anak yang cerdas secara matematis senang melihat pola dalam informasi mereka, dan mereka dapat mengingat bilangan dalam pikiran mereka untuk jangka waktu yang lebih panjang. Menjelaskan konsep-konsep secara logis, atau menyimpulkan informasi menggunakan matematika dapat meningkatkan pemahaman mereka. Armstrong menjelaskan bahwa kecerdasan logis-matematis melibatkan keterampilan mengolah angka dan/atau kemahiran menggunakan logika atau akal sehat (Armstrong, 2002:20). Anakanak yang mempunyai kelebihan dalam kecerdasan ini berpikir secara numerik atau dalam konteks pola serta urutan logis, atau dalam bentuk-bentuk cara 
berpikir logis yang lain. Berbeda dengan pendapat Campbell dan Dickinson yang menyatakan bahwa kecerdasan logis-matematis melibatkan banyak komponen, perhitungan secara matematis, berpikir logis, pemecahan masalah, pertimbangan deduktif induktif dan ketajaman pola dan hubungan (Campbell, 2007: 42). Dalam kecerdasan logis matematis, siswa bisa belajar secara efektif melalui berbagai program yang menarik yang memberikan umpan balik, misalnya games matematika, cerdas cermat matematika. Melalui program semacam ini akan menantang siswa untuk menggunakan keterampilan berpikir dalam memecahkan soal matematika. Karakterististik orang yang memiliki kecerdasan logis-matematis, yaitu : (1) Senang menyimpan sesuatu dengan rapi dan teratur, (2) Merasa senang jika mendapat arahan secara bertahap dan sistematis, (3) Mudah mengerjakan sesuatu yang berhubungan dengan menyelesaikan masalah (problem solving),( 4) Tidak menyukai ketidakteraturan atau acak-acakan, (5) Dapat mengalkulasi soal-soal hitungan dengan cepat, (6) Senang teka-teki yang rasional, (7) Sulit mengerjakan soal yang baru jika pertanyaan sebelumnya belum dijawab, (8) Kesuksesan mudah diraih jika dilakukan dengan terstruktur dan tahapan yang jelas, (9) Jika memakai computer senang bekerja melalui program database, Dan (10) Tidak merasa puas jika sesuatu yang dilakukan atau dipelajari tidak memberikan makna dalam kehidupan (Yaumi, 2013: 64). Rekomendasi tunggal ini menyediakan pedoman bagi guru-guru yang ingin meningkatkan suasana logis-matematis yang alami dalam kelas. Di kelas yang mengikuti proses-proses pembelajaran aktif seperti berikut ini akan meningkatkan pemikiran secara logis:
Menggunakan bermacam-macam strategi tanya jawab, (2) Mengajukan masalah-masalah terbuka bagi siswa untuk diselesaikan, (3) Mengkonstruksi model-model dari konsep-konsep kunci, (4) Menyuruh siswa untuk mengungkapkan pemahaman mereka dengan menggunakan objek-objek yang konkrit, (5) Memprediksikan dan membuktikan dampak atau hasil secara logis, (6) Mempertajam pola-pola dan hubungan-hubungan dalam bermacammacam fenomena, (7) Meminta siswa untuk memberikan alasan dari pernyataan dan pendapat mereka, (8) Menyediakan berbagai kesempatan untuk melakukan pengamatan dan penyelidikan, (9) Mendorong siswa untuk membangun maksud dan tujuan dari belajar mereka, Dan (10) Menghubungkan konsep-konsep atau proses-proses matematis dengan mata pelajaran lain dan juga dengan kehidupan nyata (Campbell, 2007: 43).

Dari beberapa pengertian di atas dapat disimpulkan bahwa kecerdasan logis-matematis merupakan kemampuan seseorang berkenaan dengan penguasaan konsep matematika yang menunjuk pada dimensi kognitif tentang aspek pengetahuan, pemahaman, penerapan kemampuan matematika.

Hipotesis penelitian ini adalah sebagai berikut: (1) Secara keseluruhan hasil belajar Matematika siswa yang belajar dengan strategi pembelajaran kontekstual lebih tinggi daripada siswa yang belajar dengan strategi pembelajaran ekspositori, (2) Terdapat pengaruh interaksi antara strategi pembelajaran dan kecerdasan logismatematis terhadap hasil belajar Matematika, (3) Hasil belajar Matematika siswa yang memiliki kecerdasan logis-matematis tinggi yang belajar dengan strategi pembelajaran kontekstual lebih tinggi dari siswa yang 
belajar dengan strategi pembelajaran ekspositori, Dan (4) Hasil belajar Matematika siswa yang memiliki kecerdasan logis-matematis rendah yang belajar dengan strategi pembelajaran kontekstual lebih rendah dari siswa yang belajar dengan strategi pembelajaran ekspositori.

\section{METODE PENELITIAN}

Penelitian ini dilaksanakan di SD Islam Karya Mukti pada semester ganjil tahun pelajaran 2015/2016. Penelitian ini menggunakan penelian eksperimen dengan treatment by level $2 x \quad$. Populasi terjangkau adalah seluruh siswa kelas VI SD Islam Karya Mukti yang menyebar pada beberapa kelas dan dilakukan pada semester ganjil tahun ajaran 2015/2016. Pengambilan sampel dengan teknik simple random sampling yaitu dengan teknik undian untuk menentukan kelas kelompok kontrol dan kelas kelompok eksperimen. Terdapat 82 siswa yang tergabung dalam 3 (tiga) kelas pada populasi terjangkau. Pengambilan sampel dilakukan melalui 2 tahap, yaitu: (1) Menentukan kelas eksperimen dan kelas kontrol dengan teknik undian. Kelas eksperimen akan menerima pembelajaran menggunakan strategi pembelajaran kontekstual, sedangkan kelas kontrol menggunakan strategi pembelajaran ekspositori,

Selanjutnya, semua siswa dari kedua kelompok tersebut diberikan tes untuk mengetahui tingkat kecerdasan logismatematis terhadap pelajaran Matematika. Kemudian dari hasil tes tersebut dianalisis untuk menentukan siswa yang mempunyai kecerdasan logis-matematis tinggi dan siswa yang mempunyai kecerdasan logis-matematis rendah terhadap pelajaran Matematika. Dari jumlah siswa per kelas, maka diambil sebanyak 33\% siswa kelompok tinggi sebagai kelompok yang memiliki kecerdasan logis matematis tinggi, sedangkan 33\% siswa kelompok rendah dinyatakan sebagai kelompok yang memiliki kecerdasan logis matematis rendah. Dengan demikian maka siswa yang dikategorikan memiliki kecerdasan logis matematis tinggi kelompok kelas eksperimen ada 9 siswa dari 27 siswa dan kelompok kelas kontrol ada 9 siswa dari 27 siswa. Sedangkan siswa yang dikategorikan memiliki kecerdasan logis matematis rendah kelompok eksperimen ada 9 siswa dari 27 siswa dan kelompok kelas kontrol ada 9 siswa dari 27 siswa.

Data tentang hasil belajar matematika diperoleh melalui instrumen yang dibuat untuk mengukur hasil belajar siswa pada mata pelajaran matematika berupa tes tertulis dengan bentuk objektif tes pilihan ganda. Pengukuran validitas instrumen penelitian ini menggunakan rumus korelasi point biserial. Pengujian reliabilitas dengan menggunakan formula KR-20 pada kelompok eksperimen dan kelompok kontrol. Data hasil penelitian dianalisis dengan analisis deskriptif data. Uji persyaratan analisis data dilakukan uji normalitas data dengan teknik uji Liliefors. Uji homogen varians dengan uji $F$ dan uji Barlett. Hasil pengujian persyaratan analisis menunjukkan data berdistribusi normal dan homogen. Pengujian hipotesis penelitian digunakan ANAVA dua arah $2 \times 2$ pada taraf signifikan $\alpha=0,05$. Uji lanjut untuk membandingkan antara kelompok perlakuan dan jumlah subjek penelitian setiap sel sama, maka digunakan uji Tukey.

\section{HASIL PENELITIAN DAN PEMBAHASAN}

Berdasarkan hasil pengujian persyaratan analisis berupa uji normalitas data menggunakan $\mathrm{Uji}$ 
Liliefors diperoleh bahwa secara keseluruhan dari 8 (delapan) sel kelompok data siswa dibandingkan harga $L_{o}$ lebih kecil daripada harga $L_{t}$ $(\alpha=0,05)$. Hal ini menunjukkan bahwa secara keseluruhan kelompok data siswa bersidtribusi normal. Selanjutnya hasil pengujian persyaratan analisis berupa uji homogenitas varians menggunakan uji $\mathrm{F}$ pada kelompok data siswa yang diajar melalui kedua strategi pembelajaran yang berbeda dan kelompok data siswa yang memiliki kecerdasan logis matematis yang berbeda diperoleh bahwa secara keseluruhan: harga $F_{\text {hitung }}<\mathrm{F}_{\text {tabel }}(\alpha=$ 0,05). Hal ini menunjukkan bahwa secara keseluruhan kedua kelompok data siswa memiliki variansi yang homogen. Hasil pengujian uji homogenitas varians yang menggunakan Uji Barlett pada 4 (empat) kelompok sel data siswa diperoleh $\mathrm{X}_{\mathrm{h}}^{2}(3,26)<\mathrm{X}_{\mathrm{t}}^{2}(7,81)$. Hal ini menunjukkan bahwa pada empat kelompok siswa memiliki variansi yang homogen. Rangkuman hasil perhitungan ANAVA dua arah hasil belajar matematika disajikan pada Tabel 1 berikut ini :

Tabel 1. Hasil belajar Matematika

\begin{tabular}{cccccc}
\hline $\begin{array}{c}\text { Sumber } \\
\text { Varians }\end{array}$ & $\mathbf{J K}$ & $\begin{array}{c}\mathbf{d} \\
\mathbf{b}\end{array}$ & $\begin{array}{c}\mathbf{R K} \\
(\mathbf{J K} / \mathbf{d} \\
\mathbf{b})\end{array}$ & $\begin{array}{c}\mathbf{F}_{\mathbf{h}} \\
(\mathbf{R K} / \mathbf{R} \\
\mathbf{K D})\end{array}$ & $\begin{array}{c}\mathbf{F}_{\mathbf{t}}(\boldsymbol{\alpha} \\
=\mathbf{0 , 0 5})\end{array}$ \\
\hline $\begin{array}{c}\text { Antar } \\
\text { Kolom } \\
\mathbf{( K )}\end{array}$ & 16 & 1 & 16 & 4,37 & 4,15 \\
$\begin{array}{c}\text { Antar } \\
\text { Baris } \\
(\mathbf{B})\end{array}$ & 25 & 1 & 25 & 6,83 & 4,15 \\
$\begin{array}{c}\text { Interaks } \\
\mathbf{i}(\mathbf{I})\end{array}$ & 177,78 & 1 & 177,78 & 48,58 & 4,15 \\
$\begin{array}{c}\text { Dalam } \\
(\mathbf{D})\end{array}$ & 117,11 & 32 & 3,66 & & \\
Total & 335,89 & 35 & & & \\
\hline
\end{tabular}

Berdasarkan tabel 1 hasil analisis data dengan ANAVA dua arah, maka dapat dijelaskan pengujian hipotesis sebagai berikut: Pertama, Perbedaan hasil belajar matematika siswa berdasarkan strategi pembelajaran. Dari hasil perhitungan Anava Dua Arah diperoleh $\mathrm{F}_{\text {hitung }}=4,37>\mathrm{F}_{\text {tabel }}=4,15$ pada taraf signifikan 0,05 , sehingga hipotesis statistik $\mathrm{H}_{0}$ ditolak dan $\mathrm{H}_{1}$ diterima. Hal ini menunjukkan bahwa Hasil belajar siswa yang mengikuti strategi pembelajaran kontekstual lebih tinggi daripada siswa yang mengikuti strategi pembelajaran ekspositori. Berdasarkan hasil perhitungan Anava Dua Arah menunjukkan bahwa kelompok siswa yang mengikuti strategi pembelajaran kontekstual memiliki skor rata-rata hasil belajar matematika sebesar 24,725 lebih besar dari skor rata-rata hasil belajar matematika kelompok siswa yang mengikuti strategi pembelajaran ekspositori sebesar 23,39.

Kedua, Interaksi antara strategi pembelajaran dan kecerdasan logis matematis dalam pengaruhnya terhadap hasil belajar matematika. Dari hasil perhitungan Anava Dua Arah diperoleh $\mathrm{F}_{\text {hitung }}=48,58>\mathrm{F}_{\text {tabel }}=4,15$ pada taraf signifikan 0,05 , sehingga hipotesis statistik $\mathrm{H}_{\mathrm{o}}$ ditolak dan $\mathrm{H}_{1}$ diterima. Hal ini menunjukkan bahwa terdapat interaksi yang sangat signifikan antara strategi pembelajaran dan kecerdasan logis matematis terhadap hasil belajar matematika. Bentuk interaksi tersebut secara grafis disajikan pada Gambar 1:

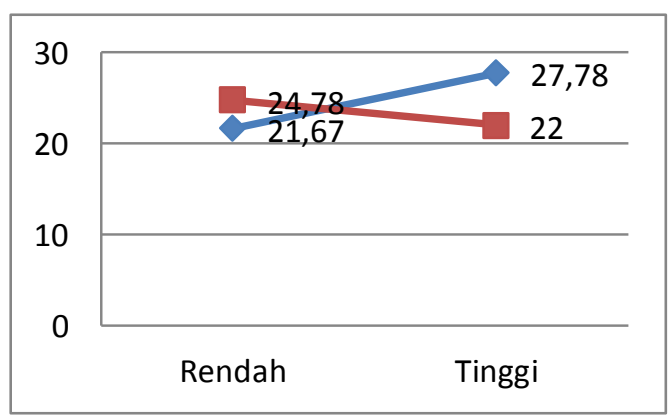

Gambar 1. Interaksi antara Strategi

Pembelajaran dan Kecerdasan Logis Matematis terhadap Hasil Belajar Matematika 
Berdasarkan hasil pengujian hipotesis penelitian terbukti bahwa ada interaksi antara strategi pembelajaran dan kecerdasan logis-matematis terhadap hasil belajar matematika siswa dengan menggunakan ANAVA dua arah 2x2 maka dilanjutkan uji lanjutan dengan uji Tukey. Uji Tukey dilakukan untuk menguji perbedaan nilai rata-rata absolut dan dua kelompok yang dipasangkan dengan cara membandingkan nilai itu dengan nilai kritis HSD (Honestly Significant Difference). Rangkuman hasil ui Tukey pada masing-masing kelompok sel yang dibandingkan pada taraf signifikan $(\alpha)=$ 0,05 disajikan dalam bentuk Tabel 2 . Tabel 2. Hasil Uji Tukey

\begin{tabular}{ccc}
\hline $\begin{array}{c}\text { Kelompok yang } \\
\text { dibandingkan }\end{array}$ & $\mathbf{Q}_{\text {hitung }}$ & $\mathbf{Q}_{\text {tabel }}$ \\
\hline $\mathbf{A}_{1} \mathbf{B}_{1}$ dengan $\mathbf{A}_{2} \mathbf{B}_{1}$ & 9,03 & 4,41 \\
$\mathbf{A}_{1} \mathbf{B}_{2}$ dengan $\mathbf{A}_{2} \mathbf{B}_{2}$ & 4,86 & 4,41
\end{tabular}

Ketiga, Perbedaan hasil belajar matematika siswa yang memiliki kecerdasan logis matematis tinggi berdasarkan strategi pembelajaran. hasil perhitungan uji Tukey diperoleh harga Qhitung sebesar 9,03, sedangkan nilai $Q_{\text {tabel }}$ untuk taraf signifikansi 0,05 sebesar 4,41. Jadi nilai $Q_{\text {hitung }}$ lebih besar dari $Q_{\text {tabel }}$, sehingga $\mathrm{H}_{\mathrm{o}}$ ditolak dan $\mathrm{H}_{1}$ diterima. Artinya, terdapat perbedaan yang signifikan terhadap hasil belajar matematika kelompok siswa yang memiliki kecerdasan logis matematis tinggi antara yang menggunakan strategi pembelajaran kontekstual dengan yang menggunakan strategi pembelajaran ekspositori

Keempat, hasil perhitungan uji Tukey diperoleh harga Qhitung sebesar 4,86 sedangkan nilai $Q_{\text {tabel }}$ untuk taraf signifikansi 0,05 sebesar 4,41. Jadi nilai

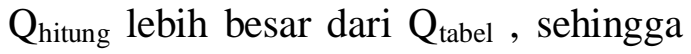
$\mathrm{H}_{\mathrm{o}}$ ditolak dan $\mathrm{H}_{1}$ diterima. Artinya, terdapat perbedaan yang signifikan terhadap hasil belajar matematika kelompok siswa yang memiliki kecerdasan logis matematis rendah antara yang menggunakan strategi pembelajaran kontekstual dengan yang menggunakan strategi pembelajaran ekspositori. Hal ini menunjukkan bahwa siswa dengan kecerdasan logis matematis rendah yang menggunakan strategi pembelajaran kontekstual memperoleh rata-rata skor hasil belajar matematika yang lebih rendah daripada yang menggunakan strategi pembelajaran ekspositori.

Hasil pengujian hipotesis yang dipaparkan di atas memberikan gambaran bahwa penggunaan strategi pembelajaran memegang peranan penting dalam proses pembelajaran. Karena dalam kegiatan pembelajaran harus memperhatikan kondisi karakteristik siswa. Strategi pembelajaran kontekstual yang digunakan pada kelas eksperimen dan strategi pembelajaran ekspositori yang digunakan pada kelas kontrol. Kegiatan pembelajaran dengan menggunakan strategi pembelajaran kontekstual pada kelas eksperimen dan strategi pembelajaran ekspositori pada kelas kontrol teruji sama-sama mempu memberi pengaruh terhadap hasil belajar matematika siswa yang memiliki kecerdasan logis matematis tinggi maupun siswa yang memiliki kecerdasan logis matematis rendah.

\section{PEMBAHASAN}

Hasil penelitian ini mengungkapkan suatu kajian fakta temuan yang diperoleh dari hasil pengujian hipotesis terhadap teori yang digunakan sebagai konseptual penelitian. Hasil pengujian hipotesis menunjukkan bahwa keempat hipotesis dalam penelitian ini telah teruji. Berikut 
pembahasan dari masing-masing hipotesis:

(1) berdasarkan hasil penelitian dan pengujian hipotesis menunjukkan bahwa hasil belajar matematika siswa yang belajar menggunakan strategi pembelajaran kontekstual lebih tinggi dibandingkan hasil belajar matematika siswa yang belajar menggunakan strategi pembelajaran ekspositori. Terlihat dari nilai rerata hasil belajar matematika siswa yang menunjukkan perbedaan antara yang menggunakan strategi pembelajaran kontekstual dan yang menggunakan strategi pembelajaran ekspositori. Dari temuan ini dapat dikatakan bahwa penggunaan strategi kontekstual dapat meningkatkan hasil belajar matematika siswa. Hipotesisi ini seiring dengan apa yang telah dijelas kan oleh Corno, L. (1989). Dalam bukunya Self-regulated learning: A volitional analysis 2) Berdasarkan hasil penelitian dan pengujian hipotesis menunjukkan bahwa terdapat interaksi antara strategi pembelajaran dan kecerdasan logis matematis siswa terhadap hasil belajar Matematika. Bagi siswa yang memiliki kecerdasan logis matematis tinggi yang mengikuti strategi pembelajaran kontekstual mencapai hasil belajar lebih tinggi daripada siswa yang mengikuti strategi pembelajaran ekspositori. Sedangkan bagi siswa yang memiliki kecerdasan logis matematis rendah yang mengikuti strategi pembelajaran ekspositori mencapai hasil belajar lebih tinggi daripada siswa yang mengikuti strategi pembelajaran kontekstual, (3) Berdasarkan hasil penelitian dan pengujian hipotesis menunjukkan bahwa hasil belajar Matematika siswa yang memiliki kecerdasan logis matematis tinggi dan menggunakan strategi pembelajaran kontekstual lebih tinggi daripada kelompok siswa yang memiliki kecerdasan logis matematis tinggi dan menggunakan strategi pembelajaran ekspositori, Dan (4) Berdasarkan hasil penelitian dan pengujian hipotesis menunjukkan bahwa hasil belajar Matematika siswa yang memiliki kecerdasan logis matematis rendah dan menggunakan strategi pembelajaran ekspositori lebih tinggi daripada kelompok siswa yang memiliki kecerdasan logis matematis rendah dan menggunakan strategi pembelajaran kontekstual. Hal ini mudah untuk dipahami sebab konsep belajar yang menggunakan Contextual learning akan membantu guru mengaitkan antara materi yang diajarkan-nya dengan situasi dunia nyata siswa dan mendorong siswa membuat hubungan antara pengetahuan yang dimilikinya dengan penerapannya dalam kehidu-pan mereka sehari-hari, dengan melibatkan tujuh komponen utama pembelaaran efektif, yakni: konstruktivisme (constructivism), bertanya (questioning), menemukan (inquiri), masyarakat belajar (learning community), pemodelan (modeling), dan penilaian sebenarnya (authentic assessment).

\section{KESIMPULAN}

Berdasarkan hasil pengujian hipotesis, ditemukan beberapa hasil penelitian sebagai berikut: (1) Secara keseluruhan hasil belajar matematika pada siswa yang mengikuti strategi pembelajaran kontekstual lebih tinggi dari siswa yang mengikuti strategi pembelajaran ekspositori. Dari temuan ini dapat disimpulkan bahwa penggunaan strategi kontekstual dapat meningkatkan hasil belajar matematika siswa, (2) Ada pengaruh interaksi antara strategi pembelajaran dan kecerdasan logis matematis terhadap hasil belajar matematika. Dari hasil temuan ini dapat disimpulkan bahwa untuk 
mengoptimalkan hasil belajar matematika siswa yang memiliki kecerdasan logis matematis tinggi dapat dilakukan dengan strategi pembelajaran kontekstual, sedangkan siswa yang memiliki kecerdasan logis matematis rendah dapat dilakukan dengan strategi pembelajaran ekspositori, (3) Untuk siswa yang memiliki kecerdasan logis matematis tinggi, hasil belajar matematika siswa yang mengikuti strategi pembelajaran kontekstual lebih tinggi daripada siswa yang mengikuti strategi pembelajaran ekspositori. Dengan demikian untuk lebih mengoptimalkan hasil belajar matematika siswa yang memiliki kecerdasan logis matematis tinggi dapat dilakukan dengan strategi pembelajaran kontekstual, Dan (4) Untuk siswa yang memiliki kecerdasan logis matematis rendah, hasil belajar matematika siswa yang mengikuti strategi pembelajaran ekspositori lebih tinggi daripada siswa yang mengikuti strategi pembelajaran kontekstual. Dengan demikian untuk meningkatkan hasil belajar siswa yang memiliki kecerdasan logis matematis rendah dapat dilakukan dengan strategi pembelajaran ekspositori.

Pemilihan strategi pembelajarab yang sesuai dengan mempertimbangkan kecerdasan logis matematis siswa dapat mengoptimalkan hasil belajar matematika. Siswa yang memiliki kecerdasan logis matematis tinggi lebih relevan diajar dengan menggunakan strategi pembelajaran kontekstual sedangkan siswa yang memiliki kecerdasan logis matematis tinggi lebih relevan diajar dengan menggunakan strategi pembelajaran ekspositori.

\section{DAFTAR RUJUKAN}

Armstrong, Thomas. (2002). Setiap Anak Cerdas, Terjemahan Rina
Buntaran. Jakarta: Gramedia Pustaka Utama.

Begg, A. (2005). Editorial: Why curriculum matters to me. Curriculum Matters, 1, 1-11.

Campbell, Linda. (2007). Metode Praktis Pembelajaran Berbasis Multiple Intelligence, Teaching \& Learning Through Multiple Intellegences. Jakarta: Intuisi Press.

Corno, L. (1989). Self-regulated learning: A volitional analysis. In B.J. Zimmerman \& D. H. Schunk (Eds.), Self-regulated learning and academic achievement (pp. 111141). New York: Springer-Verlag

Depdiknas. (2003). Standar Kompetensi Sekolah Dasar - Madrasah Ibtidaiyah. Jakarta: Depdiknas.

Hoerr, Thomas R. (2007). Buku Kerja Multiple Intelligence: Pengalaman New City School di St. Louis Missouri dalam menghargai aneka kecerdasan anak, Terjemahan Jalaluddin Rakhmat. Bandung: Kaifa.

Johnson, Elaine B. (2011). Contextual Teaching and Learning: Menjadikan Kegiatan Belajar Mengajar Mengasyikkan dan Bermakna. Bandung: Kaifa

Lwin, May. (2008). How to Multiply Your Child's Intelligence, Terjemahan Christine Sujana, Jakarta: Indeks.

Miarso,Yusufhadi. (2013). Menyemai Benih Teknologi Pendidikan. Jakarta: Kencana Prenada Media Group

Muslich, Masnur. (2009). KTSP Pembelajaran Berbasis Kompetensi dan Kontekstual. Jakarta: Bumi Aksara.

Romiszowki, A.J. (1981). Designing Instructional Systems: Decision Making in Course Planning and 
Curriculum Design, London: Kagan.

Sanjaya, Wina. (2006). Strategi Pembelajaran Berorientasi Standar Proses Pendidikan. Jakarta: Kencana.

Syah, Muhibbin. (1995). Psikologi Pendidikan dengan Pendekatan Baru. Bandung: Remaja Rosdakarya.

Suprijono, Agus. (2011). Cooperative Learning. Yogyakarta: Pustaka Pelajar.
Trianto.(2010). Mendesain Model Pembelajaran Inovatif-Progresif. Jakarta: Kencana

Van de Walle, John A. (2006). Matematika Sekolah Dasar dan Menengah Edisi Keenam. Jakarta: Erlangga.

Yamin, Martinis. (2013). Strategi dan Metode dalam Model Pembelajaran, Jakarta: Referensi.

Yaumi, Muhammad. (2013). Pembelajaran Berbasis Kecerdasan Jamak, Jakarta: Kencana Prenada Media Group. 